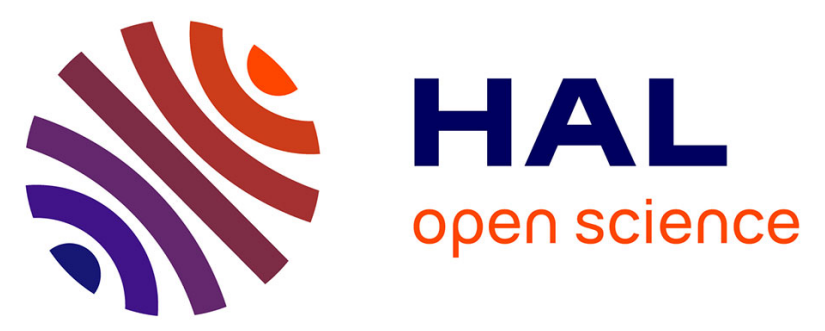

\title{
Trophic structure of two intertidal Fucus spp. communities along a vertical gradient: Similarity and seasonal stability evidenced with $\delta 13 \mathrm{C}$ and $\delta 15 \mathrm{~N}$
}

François Bordeyne, Dominique Davoult, Aline Migné, Euriell Bertaud Du

Chazaud, Cédric Leroux, Pascal Riera

\section{To cite this version:}

François Bordeyne, Dominique Davoult, Aline Migné, Euriell Bertaud Du Chazaud, Cédric Leroux, et al.. Trophic structure of two intertidal Fucus spp. communities along a vertical gradient: Similarity and seasonal stability evidenced with $\delta 13 \mathrm{C}$ and $\delta 15 \mathrm{~N}$. Journal of Sea Research (JSR), 2017, 120, pp.50-59. 10.1016/j.seares.2016.12.004 . hal-01501391

\section{HAL Id: hal-01501391 \\ https://hal.sorbonne-universite.fr/hal-01501391}

Submitted on 4 Apr 2017

HAL is a multi-disciplinary open access archive for the deposit and dissemination of scientific research documents, whether they are published or not. The documents may come from teaching and research institutions in France or abroad, or from public or private research centers.
L'archive ouverte pluridisciplinaire HAL, est destinée au dépôt et à la diffusion de documents scientifiques de niveau recherche, publiés ou non, émanant des établissements d'enseignement et de recherche français ou étrangers, des laboratoires publics ou privés. 
1 TITLE: Trophic structure of two intertidal Fucus spp. communities along a vertical gradient:

2 similarity and seasonal stability evidenced with $\delta^{13} \mathrm{C}$ and $\delta^{15} \mathrm{~N}$

4 Short title: Food web similarity in Fucus communities

5

6 Authors names:

7 François Bordeyne ${ }^{1, *}$, Dominique Davoult ${ }^{1}$, Aline Migné ${ }^{1}$, Euriell Bertaud du Chazaud ${ }^{1}$,

$8 \quad$ Cédric Leroux ${ }^{2}$ and Pascal Riera ${ }^{1}$

9

10 Affiliations and addresses:

$11{ }^{1}$ Sorbonne Universités, UPMC Univ Paris 06, CNRS, UMR 7144 AD2M, Station Biologique

12 de Roscoff, 29680 Roscoff, France

$13{ }^{2}$ Sorbonne Universités, UPMC Univ Paris 06, CNRS, FR2424, Station Biologique de

14 Roscoff, 29680 Roscoff, France

15

16 *Corresponding author: François Bordeyne

17 Email address: fbordeyne@sb-roscoff.fr

18 Phone: 0033298292333

19 Fax number: 0033298292324

20

21 ABSTRACT

22 Intertidal communities dominated by canopy-forming macroalgae typically exhibit some 23 differences in their specific composition that are related to their location along the emersion 24 gradient of rocky shores. Tidal level is also expected to affect resource availability for both 25 primary producers and consumers, potentially leading to divergence in the trophic structure of 
these communities. Furthermore, in temperate areas, the alternation of seasons has usually a large influence on the primary production and on life-history traits of numerous species, which may induce some changes in the food webs of intertidal communities. Thus, this study aimed to investigate the trophic structure of two intertidal communities located at different tidal levels, over several seasons. Focusing on the dominant species of primary producers and consumers, the food webs of the Fucus vesiculosus (Linnaeus, 1753) and Fucus serratus (Linnaeus, 1753) communities were studied during four successive seasons, using an isotopic $\left(\delta^{13} \mathrm{C}\right.$ and $\left.\delta^{15} \mathrm{~N}\right)$ approach. Due to the diversity of primary producers and consumers living in these two communities, food webs were relatively complex and composed of several trophic pathways. These food webs remained rather conserved over the successive seasons, even though some variability in isotopic signature and in diet has been highlighted for several species. Finally, despite their location at different tidal levels, the two Fucus spp. communities exhibited nearly the same trophic structure, with common consumer species displaying similar isotopic signature in both of them.

\section{KEYWORDS}

Stable isotopes; intertidal zonation; seasons; trophic groups

\section{HIGHLIGHTS}

- Food webs of intertidal fucoid communities included several trophic pathways

- Trophic structure of fucoid communities remained highly conserved over the year

- Fucoid communities from different tidal heights exhibited similar food webs 


\section{INTRODUCTION}

52 Along intertidal rocky shores of temperate areas, sheltered habitats are usually dominated by canopy-forming brown algae (Phaeophyceae) that can cover almost all the substratum. These species are established along a vertical gradient and are typically associated with numerous species of primary producers and consumers in such a way that intertidal rocky shores are composed of a succession of distinct communities from high to low tide levels (Raffaelli \& Hawkins 1999). Trophic structure of these intertidal communities has been the focus of intensive research during the past decades, due to the emergence of the stable isotopic approach (e.g. Dauby et al. 1998, Sarà et al. 2007, Riera et al. 2009, Duarte et al. 2015). To our knowledge, only one study was however carried out in the context of vertical zonation (Steinarsdóttir et al. 2009). Tidal zonation is, yet, expected to be a significant driver of community trophic structure. For instance, shore level usually controls resource access for primary producers (e.g. $\mathrm{CO}_{2} / \mathrm{HCO}_{3}{ }^{-}$and nutrients, Raven \& Hurd 2012), sessile fauna (as some species can only feed when immersed, Raffaelli \& Hawkins 1999) and mobile fauna (as the amount of available food might decrease from low to high shore levels, Underwood 1984). Trophic relationships are considered as an important component of community functioning and should be defined more accurately in the context of tidal zonation. The use of stable isotopes seems particularly powerful for this purpose, as they act as chemical tracers of energy flow (Peterson \& Fry 1987, Fry 2006). Thus, $\delta^{13} \mathrm{C}$ of a consumer usually provides information about its diet sources while its $\delta^{15} \mathrm{~N}$ value is often related to its trophic position in the food web (Zanden \& Rasmussen 2001, Caut et al. 2009).

In temperate areas, abiotic factors such as light and temperature display significant seasonal fluctuations. As a consequence, intertidal communities show seasonal pattern in their metabolism (Golléty et al. 2008, Bordeyne et al. 2015), as well as in their species richness and/or abundance (Rindi \& Guiry 2004, Dethier \& Williams 2009). These seasonal 
fluctuations potentially influence species interactions and may therefore lead to modification in their food webs. Furthermore, seasonal changes in isotopic composition of both primary producer and consumer species are regularly evidenced in coastal communities (Nordström et al. 2009, Hyndes et al. 2013), including intertidal habitats (Golléty et al. 2010, Ouisse et al. 2011). These changes, which could be related to numerous biotic and abiotic factors (Jennings et al. 2008, Vanderklift \& Bearham 2014, Viana et al. 2015), may also reflect important modifications in the trophic structure of these communities over time (McMeans et al. 2015). In this context, it appears essential to understand how seasonal variations can structure the food webs of benthic communities, and also how these communities respond to existing environmental variations (Hyndes et al. 2013).

Using a $\delta^{13} \mathrm{C}$ and $\delta^{15} \mathrm{~N}$ approach, this study focuses on the main taxa inhabiting two communities that are established at adjacent tidal levels. These two communities, widespread in temperate rocky shores, are respectively dominated by the canopy-forming species Fucus vesiculosus Linnaeus and Fucus serratus Linnaeus. This study aimed to describe the trophic structure of these communities at four periods of the year, assuming that the alternation of seasons is likely to generate significant fluctuations of food webs. Comparisons between communities were also carried out to test the hypothesis that food webs vary according to the tidal level.

\section{MATERIAL AND METHODS}

\subsection{Study site}

The study site is located in front of the Station Biologique de Roscoff, in the southwestern part of the English Channel (Brittany, France) (4843.743’N, $\left.3^{\circ} 59.407^{\prime} \mathrm{W}\right)$. It consisted of an intertidal boulder reef subjected to semi-diurnal tidal cycle, with maximal amplitude of about $9 \mathrm{~m}$. This semi-sheltered rocky shore is characterized by a vertical succession of communities 
101 dominated by canopy-forming Phaeophyceae, where the Fucus vesiculosus and F. serratus

102 communities are characteristic of the mid-intertidal (3.0 to $4.0 \mathrm{~m}$ above chart datum) and low 103 mid-intertidal (2.5 to $3.0 \mathrm{~m}$ above chart datum) respectively. These communities are mainly 104 composed of dense Fucus spp. canopies, covering up to $100 \%$ of the substratum, which are 105 associated with miscellaneous epibionts (i.e. algae and sessile invertebrates directly attached 106 to the Fucus, see Wahl 2009). They are also made up of sub-canopy and encrusting algae, as 107 well as microphytobenthos, and phytoplankton during high tide. Finally, these communities 108 also support a diverse pool of mobile invertebrates (Raffaelli \& Hawkins 1999, Migné et al. 109 2015).

\subsection{Sampling and preparation for stable isotopes analysis}

112 For both $F$. vesiculosus and $F$. serratus communities, the most representative taxa of food sources (i.e. erect and encrusting algae, and epilithon) and consumers were collected by hand

114 during low tide, in four successive seasons (September and December 2013 and March and June 2014, see Supplementary material for the list of sampled taxa). After collection, samples were frozen at $-18{ }^{\circ} \mathrm{C}$ for later processing. Particular attention was taken to collect consumers

117 from the main trophic groups (filter-feeders, grazers and predators), based on literature 118 knowledge (e.g. Dauby et al. 1998, Riera et al. 2009, Golléty et al. 2010). Stable isotope data 119 for marine suspended particulate organic matter (POM) were obtained from the SOMLIT 120 network, in a place located at approximately $600 \mathrm{~m}$ of our study site (Estacade sampling

121 point, Roscoff, France, data available at http://somlit-db.epoc.u-bordeaux1.fr/bdd.php).

122 In the laboratory, erect algae were carefully cleaned in filtered seawater $(0.45 \mu \mathrm{m})$ to remove 123 detrital fragments and attached organisms. The encrusting ones were scrubbed in filtered 124 seawater, which was then filtered onto pre-combusted filters (Whatman GF/F glass microfiber 125 filters). In order to remove inorganic carbon of the encrusting Rhodophyceae 
Phymatolithon lenormandii, $\mathrm{HCl} 1 \mathrm{~N}$ was added to seawater prior to filtration. Epilithon was

127 gently removed from small boulders using a smooth brush and collected in filtered seawater,

128 then filtered onto pre-combusted filters. Regarding consumers, organisms belonging to the

129 Cnidaria (except campanulariidae), Mollusca, Arthropoda (except amphipods) and

130 Echinodermata phyla were treated at the individual level, while for colonial taxa (i.e.

131 campanulariidae, Bryozoa and Ascidiacea), Spirorbis sp. and amphipods, several organisms

132 were pooled together to get enough material for accurate stable isotope analyses. Gastropods

133 were extracted from their shell to take off foot muscle, whereas for decapods, muscle was

134 taken off from their pereiopods. For Asterina gibbosa, amphipods, campanulariidae and

135 polyclinidae, half of the samples were acidified to remove inorganic carbon $(\mathrm{HCl} 1 \mathrm{~N})$ while

136 the other part remained untreated. $\delta^{13} \mathrm{C}$ measurements were performed on acidified samples

137 and $\delta^{15} \mathrm{~N}$ on untreated ones, as advised by Schlacher \& Connolly (2014). Finally, all samples

138 were rinsed with distilled water, before being dried $\left(60^{\circ} \mathrm{C}, 48 \mathrm{~h}\right)$ and ground to a fine

139 homogeneous powder using an agate mortar and pestle.

140

141 Carbon and nitrogen stable isotopes ratios were determined using a Flash EA 1112 CHN

142 analyzer (ThermoFinningan) coupled with a Finnigan Delta Plus mass spectrometer, via a

143 Finnigan Con-Flo III interface. Data are expressed in the standard $\delta$ unit:

$$
\delta X(\%)=\left[\left(\frac{R_{\text {sample }}}{R_{\text {standard }}}\right)-1\right] \times 10^{3}
$$

144 With $X$ is ${ }^{13} \mathrm{C}$ or ${ }^{15} \mathrm{~N}$ and $\mathrm{R}$ is ${ }^{13} \mathrm{C} /{ }^{12} \mathrm{C}$ ratio for carbon or ${ }^{15} \mathrm{~N} /{ }^{14} \mathrm{~N}$ ratio for nitrogen.

$145 \quad \delta^{13} \mathrm{C}$ and $\delta^{15} \mathrm{~N}$ were calculated in relation to the certified reference materials Vienna-Pee Dee

146 Belemnite-limestone (V-PDB) and atmospheric di-nitrogen $\left(\mathrm{N}_{2}\right)$. The V-PDB and $\mathrm{N}_{2}$ at air-

147 scales were achieved using in-house protein standards, calibrated against NBS-19 and IAEA

$148 \mathrm{~N} 3$ reference materials. The standard deviation of repeated measurements of $\delta^{13} \mathrm{C}$ and $\delta^{15} \mathrm{~N}$ 
149 values of the laboratory standard was 0.10 \%o versus V-PDB and $0.05 \%$ versus at-air, 150 respectively.

\subsection{Taxonomic diversity and density of gastropod grazers}

Gastropod grazers (hereafter referred to as "grazers”) constitute the most abundant group of consumers in these communities (approx. 95\% of the countable fauna) and likely play a significant role in organic matter fluxes within the food webs. The taxonomic diversity of these grazers was monitored in the same areas and at the same periods than sampling for stable isotopes analyses (i.e. September and December 2013, and March and June 2014).

Thus, at each season, grazers were identified at the species level and counted in five replicates of $0.1 \mathrm{~m}^{2}$ randomly chosen in each community. To account for spatial variability, intra-

160 community replicates were 3 to $10 \mathrm{~m}$ away one from each other.

\subsection{Data analysis}

The trophic structure of each community, its temporal fluctuations, and the potential trophic

164 relationships between diets and consumers, were investigated by drawing dual-isotope plots at

165 each sampling period. The “community-wide” isotopic metrics developed by Cucherousset \&

166 Villéger (2015) (i.e. isotopic richness, divergence, dispersion, evenness and uniqueness) were

167 used as a complement to these dual-isotope plots. The isotopic richness is related to the area

168 of the bi-dimensional isotopic space that is filled by all the taxa while the isotopic divergence,

169 dispersion, eveness and uniqueness are related to the distribution of taxa in this space,

170 providing information about trophic diversity and redundancy. These metrics have the benefit

171 to be mathematically independent of the number of replicates used and allow accounting for

172 abundance/biomass of taxa, when available. They were calculated at each sampling period

173 and for each community, using the R functions computed by Cucherousset \& Villéger (2015), 
174 with R software, version 3.2.2 (R Core Team 2015). Their coefficient of variation across

175 seasons was used to discuss about the seasonal variability in the trophic structure of these two 176 communities.

177 Bayesian stable isotope mixing models (SIAR, Parnell et al. 2010, Parnell \& Jackson 2013) 178 were implemented to estimate the relative contribution of food sources to the diet of several 179 consumers, at each season, and for each community. To do so, trophic enrichment factors of $0.28 \pm 0.23 \%$ for $\delta^{13} \mathrm{C}$ and of $2.5 \pm 0.68 \%$ for $\delta^{15} \mathrm{~N}$ were assumed (Caut et al. 2009). Thus,

181 these mixing models were run for a set of filter-feeders selected for each community, 182 implementing POM and erect algae as potential food sources. Erect algae were used 183 considering that they may be consumed by filter-feeders through detritus (Leclerc et al. 2013), 184 despite that degradation process might affect their isotopic composition (Lehmann et al. 185 2002). Mixing models were also run for a set of grazers selected for each community, implementing epilithon and erect algae as potential food sources. Grazer selection was realized according to Hawkins et al. (1989), in such a way that diversity of feeding behaviours

188 and of radula types was maximised. In the F. serratus community, some erect Rhodophyceae 189 were pooled together according to their characteristics, to limit the number of potential food sources (Phillips et al. 2014).

192 For comparisons between communities, we first calculated the overall level of isotopic 193 overlap between the two communities using the isotopic overlap metrics (isotopic similarity 194 and nestedness) developed by Cucherousset \& Villéger (2015), from the average isotopic 195 signature of each taxon. We also focused on consumer taxa present in both communities (i.e. 196 shared consumers, see Supplementary Material for their identities). Their average $\delta^{13} \mathrm{C}$ and $197 \delta^{15} \mathrm{~N}$ obtained in the $F$. vesiculosus community were plotted against those obtained in the $F$. 198 serratus community. Slopes and intercepts of a Model II regression were then calculated 
199

according to the major axis method, using the "Imodel2” R package version 1.7-2 (Legendre 2014), for both $\delta^{13} \mathrm{C}_{\text {Fves }}$ vs $\delta^{13} \mathrm{C}_{\mathrm{Fser}}$ and $\delta^{15} \mathrm{~N}_{\text {Fves }}$ vs $\delta^{15} \mathrm{~N}_{\text {Fser }}$ plots. Student's t-tests were performed to test if slopes and intercepts of regressions were significantly different from 1 and 0 , respectively. If not, it would indicate that, on average, the shared consumers' exhibited similar isotopic signature in the two communities.

Focusing on grazers, potential differences between communities were first investigated in terms of taxonomic diversity (i.e. distribution of abundances among taxa) using clustering analysis (group average) and one-way ANOSIM test (for each community, the four seasonal samples were considered as replicates). These analyses were performed on similarity matrix calculated from Bray-Curtis similarity index on square-root transformed abundances, using PRIMER software, version 6.1.12 (Clarke \& Gorley 2006). Then, potential difference between communities in term of isotopic diversity of grazers was investigated using the isotopic diversity metrics (isotopic richness, divergence, dispersion, evenness and uniqueness, (Cucherousset \& Villéger 2015). These isotopic metrics were calculated at each season and for each community, from grazer isotopic signatures, with and without weighting them by their abundances. Clustering analysis and one-way ANOSIM tests were then performed for each condition on similarity matrices calculated using Bray-Curtis similarity index on the five metrics, following the procedure previously described.

\section{RESULTS}

\subsection{Trophic structure of Fucus spp. communities and seasonal variability}

For each community, primary sources were distributed over a large range of $\delta^{13} \mathrm{C}$ over the sampling seasons. For the F. vesiculosus community, Caulacanthus ustulatus, POM and epilithon were the most ${ }^{13} \mathrm{C}$-depleted sources, and displayed $\delta^{13} \mathrm{C}$ ranging from -20.3 to $24.0 \%$, according to sampling seasons. Ascophyllum nodosum, F. vesiculosus, Ulva spp. and 
224 Hildenbrandia rubra were more ${ }^{13} \mathrm{C}$-enriched and showed $\delta^{13} \mathrm{C}$ values ranging from -13.0 to -

$22518.4 \%$, according to sampling seasons. These sources were mainly discriminated by their $226 \delta^{15} \mathrm{~N}$, with $A$. nodosum and $F$. vesiculosus being on average more ${ }^{15} \mathrm{~N}$-depleted (5.1 to $7.4 \%$ \%) 227 than Ulva spp. and H. rubra (6.2 to $8.9 \%$, Figure 1). For the F. serratus community, 228 C. ustulatus, Chondracanthus acicularis, POM and epilithon were the most ${ }^{13}$ C-depleted 229 sources, and displayed $\delta^{13} \mathrm{C}$ values ranging from -19.5 to $-25.0 \%$, according to sampling 230 seasons. The other sources were more ${ }^{13} \mathrm{C}$-enriched (-14.8 to $-19.9 \%$ ). Among them, 231 F. serratus was the most ${ }^{15} \mathrm{~N}$-depleted (3.0 to $5.7 \%$ ), while Ulva spp., H. rubra, 232 Mastocarpus stellatus and P. lenormandii were more closely related $\left(\delta^{15} \mathrm{~N}\right.$ ranging from 6.5 233 to $9.7 \%$ o, Figure 2). Regarding consumers, filter-feeders were on average the most ${ }^{13} \mathrm{C}$ 234 depleted, with $\delta^{13} \mathrm{C}$ values ranging from -16.5 to $-20.8 \%$ for the $F$. vesiculosus community 235 and from -15.2 to $-21.2 \%$ for the F. serratus community, according to sampling seasons. In 236 comparison, grazers were more ${ }^{13} \mathrm{C}$-enriched, with values ranging from -13.9 to $-16.4 \%$ or 237 the F. vesiculosus community and from -13.1 to $-17.0 \%$ o for the F. serratus community, 238 according to sampling seasons. Predators occupied the top of the food webs, and were the 239 most ${ }^{15} \mathrm{~N}$-enriched consumers. They displayed $\delta^{15} \mathrm{~N}$ values ranging from 9.2 to $13.0 \%$ for the 240 F. vesiculosus community (filter-feeders and grazers: 7.2 to $10.8 \%$, Figure 1 ) and from 7.7 to $241 \quad 14.0 \%$ for the F. serratus community (filter-feeders and grazers: 6.0 to $10.3 \%$, Figure 2), 242 according to sampling seasons.

243 The five isotopic metrics showed low variability across seasons, as their coefficient of 244 variation varied between 3.8 and $14.6 \%$ in the F. vesiculosus community and between 2.4 and $24525.4 \%$ in the F. serratus community (Table 1). Only isotopic richness and uniqueness of the 246 F. serratus community exhibited a coefficient of variation higher than $15 \%$. This was mainly 247 due to the high ${ }^{13} \mathrm{C}$ and/or ${ }^{15} \mathrm{~N}$ depletions of two basal sources in some seasons (i.e. epilithon 
248 was ${ }^{13} \mathrm{C}$ and ${ }^{15} \mathrm{~N}$ depleted in both December and March, and F. serratus was ${ }^{15} \mathrm{~N}$ depleted in 249 March, Figure 2).

250 Relative contributions of potential food sources to the diet of consumers were highly variable 251 between sampling seasons (Table 2). In the F. vesiculosus community, the contribution of 252 POM to the diet of filter-feeders was maximal in September and June (17.2 to $49.4 \%$ on 253 average) and minimal in December and March (8.8 to 13.1\% on average). In contrast, erect 254 macroalgae were the main resources to filter-feeders in December and March (86.9 to 91.2\% 255 on average, Table 2). For grazers, no clear seasonal trend in diet was evidenced, even though 256 Ulva spp. and F. vesiculosus constituted their main trophic resources in March (27.0 to 77.6\% 257 on average) and in June (42.9 to $71.2 \%$ on average), respectively. In the F. serratus 258 community, the contribution of POM to the diet of filter-feeders was maximal in September 259 and June (29.5 to $77.6 \%$ on average) and minimal in December and March (6.1 to $16.1 \%$ on 260 average) as well. Erect macroalgae were their main resources in December and March (83.9 261 to $93.9 \%$ on average, Table 2). No clear seasonal trend in diet of grazers was evident, even 262 though F. serratus constituted their main trophic resources in June $(69.2$ to $86.3 \%$ on 263 average).

\subsection{Comparisons between communities}

266 No seasonal trend in trophic structure has been observed for these two intertidal communities. 267 As well, when comparisons between communities were performed at each season, any 268 difference were evidenced, neither considering the functional isotopic space of whole 269 communities (i.e. high isotopic similarity and isotopic nestedness), nor considering the 270 isotopic composition $\left(\delta^{13} \mathrm{C}\right.$ and $\left.\delta^{15} \mathrm{~N}\right)$ of consumers species present in both communities. 271 Therefore, comparisons between communities were performed using an average isotopic 272 signature of each taxon, obtained after pooling the stable isotope values of the different 
273 sampling periods. Considering these year-round means in isotopic signature, the two 274 communities presented an isotopic similarity of 0.779 and an isotopic nestedness of 0.894 275 (Figure 3). Almost all the taxa (43 of 52) were included in the intersection of the two isotopic 276 spaces. Regarding the consumers shared by the two communities, the model II regressions of 277 dual plots exhibited significant Pearson's coefficient (For $\delta^{13} \mathrm{C}_{\text {Fves }}$ vs $\delta^{13} \mathrm{C}_{\text {Fser }}, \mathrm{n}=14$, $278 \mathrm{R}=0.876, p<0.001$; for $\delta^{15} \mathrm{~N}_{\text {Fves }}$ vs $\delta^{15} \mathrm{~N}_{\text {Fser }}, \mathrm{n}=14, \mathrm{R}=0.953, p<0.001$ ) (Figure 4). The 279 slopes of regressions were equal to 1.2 and 1.0 for $\delta^{13} \mathrm{C}_{\text {Fves }}$ vs $\delta^{13} \mathrm{C}_{\text {Fser }}$ and $\delta^{15} \mathrm{~N}_{\text {Fves }}$ vs $\delta^{15} \mathrm{~N}_{\text {Fser, }}$, 280 respectively, while intercepts were equal to 2.9 and 0.3 , respectively. These slopes and 281 intercepts were not significantly different from 1 and 0 , respectively (For $\delta^{13} \mathrm{C}_{\mathrm{Fves}}$ vs $\delta^{13} \mathrm{C}_{\mathrm{Fser}}$, $282 \mathrm{t}=1.42, p=0.091$ for the slope and $\mathrm{t}=1.49, p=0.080$ for the intercept; for $\delta^{15} \mathrm{~N}_{\text {Fves }}$ vs $283 \delta \delta^{15} \mathrm{~N}_{\mathrm{Fser}}, \mathrm{t}=0.13, p=0.450$ for the slope and $\mathrm{t}=0.40, p=0.349$ for the intercept).

284 In both communities, Gibbula spp., Littorina spp. and Patella vulgata were the most 285 dominant taxa of grazers: G. umbilicalis being the most abundant species in the F. vesiculosus 286 community (96 to 208 individuals per $\mathrm{m}^{2}$ ) and G. pennanti was most abundant species in the F. serratus community (130 to 508 individuals per $\mathrm{m}^{2}$, Table 3). Clustering analysis 288 performed on the taxonomic diversity of grazers discriminated the two communities (Figure $2895 a)$, which were significantly different according to the ANOSIM test $(\mathrm{R}=0.75, p=0.029)$. 290 When performed on isotopic diversity metrics, these analyses did not allow to significantly 291 discriminate the two communities, neither when they were conducted on unweighted data 292 (ANOSIM test, $\mathrm{R}=0.26, p=0.083$, Figure $5 \mathrm{~b}$ ), nor when conducted on data weighted by 293 abundance of grazers (ANOSIM test, $\mathrm{R}=0.12, p=0.229$, Figure $5 c$ ).

\section{DISCUSSION}


By analysing isotopic composition of the main taxa inhabiting the Fucus vesiculosus and

298 F. serratus communities, we attempted to depict their global trophic structure. At each season and in each community, groups of consumers were discriminated as filter-feeders, grazers and

300 predators, despite some overlap in their isotopic signatures. As expected, filter-feeders were 301 the most ${ }^{13} \mathrm{C}$-depleted consumers, while predators were the most ${ }^{15} \mathrm{~N}$-enriched and occupied 302 the top of the food webs. Both sources and consumers were distributed over large $\delta^{13} \mathrm{C}$ and $303 \delta^{15} \mathrm{~N}$ ranges, suggesting that the Fucus spp. communities are characterized by a complex 304 trophic structure (Golléty et al. 2010). This complexity may have been however 305 underestimated during this study, as the ultimate top predators of these communities (i.e. 306 fishes and shore birds, Ellis et al. 2007), as well as one potential food source (epibiotic 307 biofilms) were not sampled. Despite that, the large $\delta^{15} \mathrm{~N}$ range of consumers (i.e. $\delta^{15} \mathrm{~N}$ 308 extended over 4.7 to $7.4 \%$ according to the sampling period) reveals the presence of several 309 trophic levels within the Fucus spp. communities. The heterogeneous distribution in $\delta^{15} \mathrm{~N}$ of 310 primary consumers prevented, however, to attribute an accurate trophic position to each 311 consumer (Post 2002, Riera et al. 2009). As well, their large $\delta^{13} \mathrm{C}$ range is characteristic of the 312 occurrence of several trophic pathways, as previously reported in rocky shore habitats 313 (Golléty et al. 2010, Leclerc et al. 2013). This likely results from the high diversity of food 314 sources and feeding behaviors of invertebrates (Riera et al. 2009), which are favored by the 315 multitude of microhabitats that usually characterized rocky shores (Schaal et al. 2010, 2011). 316 Mixing models also highlighted the occurrence of several trophic pathways in fucoid 317 communities. Thus, filter-feeders were supposed to rely mainly on POM and on several 318 species of erect algae through the detrital pathway. As well, the diet of grazers was mainly 319 based on a mix of different species of algae (i.e. Fucus, Ulva spp., A. nodosum, M. stellatus). 320 According to these results, filter-feeders and grazers can be considered as generalist species. 321 Therefore, Fucus species did not constitute the cornerstone of these food webs, supplying the 
vast majority of organic carbon for primary consumers (with the exception of June for grazers), as we might reasonably expect from their abundance (i.e. 1.50 to $11.80 \mathrm{~kg}$ of fresh weight $\mathrm{m}^{-2}$ for Fucus canopies; 0.02 to $0.28 \mathrm{~kg}$ of fresh weight $\mathrm{m}^{-2}$ for all other erect macroalgae, Bordeyne et al., unpublished data). However, fucoid species are usually considered to have poor nutritional values and can induce anti-grazing defence that may repel primary consumers (Molis et al. 2006). Therefore, primary consumers may show food preference toward more nutritional species (Lubchenco 1978, Littler \& Littler 1980, Watson \& Norton 1985), despite their lower abundance. Epibiotic biofilms, while not sampled here, may also constitute a complementary trophic resource for some species of grazers, notably those living on fucoid fronds such as Littorina obtusata (see Norton et al. 1990 and references therein). Interestingly, according to its isotopic signature and the results of mixing models, the introduced alga C. ustulatus has very low contribution to the diet of grazers. This species, first recorded close to our study site almost 30 years ago (Rio \& Cabioch 1988), was suggested to be unpalatable for native consumers due to production of secondary metabolites (Smith et al. 2014). However, filter-feeders may rely on this species through the detrital pathway. Finally, we should mention that the wide ranges in specific contributions obtained from mixing models reveal some uncertainties, and have to be considered with caution (Phillips et al. 2014).

\subsection{Seasonal variability of trophic structure}

The year-round analysis of the isotopic composition of the main taxa inhabiting the F. vesiculosus and F. serratus communities revealed an overall preservation of their food webs across seasons. This trend, depicted by comparing the biplots drawn at each season, was supported by the low values of the coefficient of variation across seasons for isotopic diversity metrics, especially in the F. vesiculosus community. Such preservation of trophic 
structure across seasons has already been noticed for a Fucus-dominated community (Schaal

348 et al. 2010), even though the studied community was subjected to a strong anthropogenic 349 pressure, which may have influenced isotopic composition of both sources (Viana et al. 2015) 350 and consumers (Warry et al. 2016). Thus, the year-round preservation of food webs we observed in non-impacted fucoid communities could have major implications regarding our 352 knowledge of their dynamics. Indeed, temporal modification of species richness and/or 353 abundance is generally considered as a key process in temperate habitats (Dethier \& Williams 354 2009) and could potentially lead to a seasonality in resource availability, as observed in the Arctic environments. Such seasonality finally leads to large modifications of food webs in these extreme environments (Forest et al. 2008, Darnis et al. 2012). In the present study, however, most of the common macroalgae are perennial (e.g. Fucus spp., M. stellatus), providing constant resources for grazers, despite the fall to spring decrease in abundance of ephemeral alga Ulva spp. (Migné et al. 2015). Therefore, grazers do not need to switch their diet over the course of the year, explaining their temporal conservation within food webs. In contrast, filter-feeders showed a partial switch in diet over the year, according to the results of 362 mixing models. They were found to rely mainly on phytoplankton-dominated POM during 363 summer and on macroalgae-derived organic matter during winter, which is consistent with 364 seasonal variations in abundance of phytoplankton observed close to our study area (SOMLIT data). Such switch in diet has already been observed in kelp forests of Brittany (Leclerc et al. 2013), and strengthens the idea that macroalgae-derived detritus are a significant food source 367 for filter-feeders (Sarà et al. 2007, Crawley et al. 2009, Schaal et al. 2010, Miller \& Page 368 2012). They are therefore suggested to be opportunistic species relying on the most abundant 369 food source (Ricciardi \& Bourget 1999, Schaal et al. 2010). In spite of this temporal diet variability, the average trophic position of this functional group in the two communities 371 remained unchanged, and filter-feeders stayed ${ }^{13} \mathrm{C}$-depleted compared to grazers, all over the 
year. The relative seasonal conservation of predators within the food webs was probably due

373 to the seasonal consistency of their potential diet (i.e. primary consumers) but should also

374 result from a relative degree of omnivory and opportunism (Thompson et al. 2007, Silva et al.

375 2010, Duarte et al. 2015). Finally, the overall preservation of trophic structure across seasons

376 observed despite some seasonal changes in taxonomic diversity of consumers, suggests that

377 some redundancy in the feeding behaviour of these species (Hawkins et al. 1989, Golléty et

378 al. 2010) helps to keep a relative food web stability over time (Christie et al. 2009).

379 The high degree of conservation of their trophic structures exhibited by fucoid communities 380 during the sampling year could lead to further new insights about dynamics of these habitats. 381 These results should, however, be complemented by the addition of densities or biomasses for 382 each taxa, as this may thoroughly modify the vision we have of trophic relationships (Rigolet 383 et al. 2015).

\subsection{Comparisons between communities}

386 By analysing isotopic composition of taxa living in these communities, we had the prospect to do comparisons in the context of vertical zonation of intertidal habitats. Using communitywide metrics, we highlighted an important similarity in the average trophic structure of the two Fucus spp. communities. This was supported by the large number of taxa present in the common isotopic space. Despite some differences in the species richness and composition 391 between these two communities (Davoult et al., unpublished data), they shared a roughly similar isotopic functional space, suggesting that the same trophic functions are undertaken by different species in the F. vesiculosus and F. serratus communities. This is consistent with the

394 fact that intertidal communities are mostly composed of generalists and opportunistic species, 395 that rely mainly on the most abundant food sources (Steinarsdóttir et al. 2009). Such plasticity 396 in diet could favour growth rates of consumers, as demonstrated by Lee et al. (1985), 
providing them some benefit in intertidal habitats. However, the two Fucus spp. communities

398 exhibited significant differences in their photosynthetic activity over the year (Bordeyne et al. 2015), potentially leading to important differences in the amount of carbon accumulation at the base of the food webs, and in carbon fluxes toward top predators. Again, further 401 investigations taking into account taxon abundances are needed to understand more faithfully 402 the trophodynamics of these communities.

403 Although the $F$. vesiculosus and F. serratus communities exhibit some differences in their 404 specific composition, several taxa of consumers live commonly in the two communities. 405 These taxa were found to exhibit, on average, similar isotopic composition, whether they were 406 found in the F. vesiculosus community or in the F. serratus one. Steinarsdóttir et al. (2009) 407 observed a similar pattern on a few number of invertebrate species from Icelandic coast. 408 These results are particularly interesting since most of the considered taxa are sessile or slow 409 moving invertebrates. Therefore, this suggests that they used similar diet resources in both 410 locations. The case of the green crab Carcinus maenas is slightly different, as for this highly 411 mobile species, migration toward higher intertidal levels for foraging activity has been shown 412 to be usual during high tide (Silva et al. 2010). This species can thus be considered as a 413 coupler that underlie landscape level food webs, as defined by Rooney et al. (2008).

414 Diversity monitoring highlighted significant differences in the composition of grazers 415 between the two communities, in accordance with the tidal control of species distribution and 416 abundances (Raffaelli \& Hawkins 1999). However, when considering isotopic composition, 417 no significant difference between communities was evidenced, whether the abundance of 418 grazers is accounted for or not. These results suggest that the two groups of grazers exhibited 419 similar trophic functions within the two communities, despite some differences in species 420 identities and abundances. Besides, within each community, the diversity of radula types and 421 feeding mechanisms described for these grazers indicated that some functional 
complementarity occurs (for instance, $P$. vulgata is considered as a scraper of hard substrata, while Gibbula spp. seem rather to brush algae, Hawkins et al. 1989), and is likely to promote species coexistence in relatively high abundances.

By focusing on grazers, the present study confirms that considering species abundance or biomass in association with stable isotope approach is a fresh opportunity to bring some new insights about community functioning (Cucherousset \& Villéger 2015, Rigolet et al. 2015). In this study, this approach allowed us to exclude significant difference in the trophic structure of grazers between the two communities, as discussed before. Without this, any evident conclusion would have been drawn, as the doubt could still subsist with a p-value of 0.08 (obtained for unweighted isotopic data of grazers), especially when specific composition and abundance varied between the two communities.

\subsection{Conclusion}

This study highlighted that the two widespread Fucus vesiculosus and F. serratus communities exhibited trophic structures that remained highly conserved over a year, despite some seasonal fluctuations in physiological processes and in species composition and abundance. Thus, such food web approaches should be carried on, not only at the seasonal scale but also at various temporal scales (McMeans et al. 2015), to better understand the dynamics of food webs, especially according to the specific features of their environment. Furthermore, the two Fucus spp. communities exhibited similar trophic structure while they are located at different shore levels and exhibit some differences in their specific composition. In this context of vertical zonation, it would be interesting to go further, and for instance have a look to the specific composition and food webs of several communities dominated by canopy-forming macroalgae that are established on the whole intertidal gradient. 


\section{ACKNOLEDGMENTS}

448 The authors thank the SOMLIT network for providing isotopic data of particulate organic 449 matter of our study area. Two anonymous reviewers and the associate editor are thanked for 450 constructive comments. This work benefited from the support of the Brittany Regional 451 Council and of the French Government through the National Research Agency with regard to 452 the investment expenditure programme IDEALG ANR-10-BTBR.

453 


\section{BIBLIOGRAPHY}

Bordeyne F, Migné A, Davoult D (2015) Metabolic activity of intertidal Fucus spp. communities: evidence for high aerial carbon fluxes displaying seasonal variability. Mar Biol 162:2119-2129

Caut S, Angulo E, Courchamp F (2009) Variation in discrimination factors $\left(\Delta^{15} \mathrm{~N}\right.$ and $\left.\Delta^{13} \mathrm{C}\right)$ : the effect of diet isotopic values and applications for diet reconstruction. J Appl Ecol 46:443-453

Christie H, Norderhaug K, Fredriksen S (2009) Macrophytes as habitat for fauna. Mar Ecol Prog Ser 396:221-233

Clarke K, Gorley R (2006) PRIMER v6: User Manal/Tutorial, PRIMER-E. Plymouth

Crawley K, Hyndes G, Vanderklift M, Revill A, Nichols P (2009) Allochthonous brown algae are the primary food source for consumers in a temperate, coastal environment. Mar Ecol Prog Ser 376:33-44

Cucherousset J, Villéger S (2015) Quantifying the multiple facets of isotopic diversity: new metrics for stable isotope ecology. Ecol Indic 56:152-160

Darnis G, Robert D, Pomerleau C, Link H, Archambault P, Nelson RJ, Geoffroy M, Tremblay J-É, Lovejoy C, Ferguson SH, Hunt BPV, Fortier L (2012) Current state and trends in Canadian Arctic marine ecosystems: II. Heterotrophic food web, pelagic-benthic coupling, and biodiversity. Clim Change 115:179-205

Dauby P, Khomsi A, Bouquegneau J-M (1998) Trophic relationships within intertidal communities of the Brittany coasts: a stable carbon isotope analysis. J Coast Res:1202-1212

Dethier MN, Williams SL (2009) Seasonal stresses shift optimal intertidal algal habitats. Mar Biol 156:555-567 
Duarte L, Rossi F, Docal C, Viejo R (2015) Effects of alga Fucus serratus decline on benthic assemblages and trophic linkages at its retreating southern range edge. Mar Ecol Prog Ser 527:87-103

Ellis JC, Shulman MJ, Wood M, Witman JD, Lozyniak S (2007) Regulation of intertidal food webs by avian predators on New England rocky shores. Ecology 88:853-863

Forest A, Sampei M, Makabe R, Sasaki H, Barber DG, Gratton Y, Wassmann P, Fortier L (2008) The annual cycle of particulate organic carbon export in Franklin Bay (Canadian Arctic): Environmental control and food web implications. J Geophys Res Oceans 113

Fry B (2006) Stable Isotope Ecology. Springer New York, New York, NY

Golléty C, Migné A, Davoult D (2008) Benthic metabolism on a sheltered rocky shore: role of the canopy in the carbon budget. J Phycol 44:1146-1153

Golléty C, Riera P, Davoult D (2010) Complexity of the food web structure of the Ascophyllum nodosum zone evidenced by a $\delta^{13} \mathrm{C}$ and $\delta^{15} \mathrm{~N}$ study. J Sea Res 64:304312

Hawkins SJ, Watson DC, Hill AS, Harding SP, Kyriakides MA, Hutchinson S, Norton TA (1989) A comparison of feeding mechanisms in microphagous, herbivorous, intertidal, prosobranchs in relation to resource partitioning. J Molluscan Stud 55:151-165

Hyndes GA, Hanson CE, Vanderklift MA (2013) The magnitude of spatial and temporal variation in $\delta^{15} \mathrm{~N}$ and $\delta^{13} \mathrm{C}$ differs between taxonomic groups: Implications for food web studies. Estuar Coast Shelf Sci 119:176-187

Jennings S, Maxwell T, Schratzberger M, Milligan S (2008) Body-size dependent temporal variations in nitrogen stable isotope ratios in food webs. Mar Ecol Prog Ser 370:199_ 501 206 
Leclerc J, Riera P, Leroux C, Lévêque L, Davoult D (2013) Temporal variation in organic matter supply in kelp forests: linking structure to trophic functioning. Mar Ecol Prog Ser 494:87-105

Lee WY, Zhang XK, Van Baalen C, Arnold CR (1985) Feeding and reproductive performace of the harpacticoid Tisbe carolinensis (Copepoda, Crustacea) in four algal cultures. Mar Ecol Prog Ser 24:273-279

Legendre P (2014) lmodel2: Model II Regression.

Lehmann MF, Bernasconi SM, Barbieri A, McKenzie JA (2002) Preservation of organic matter and alteration of its carbon and nitrogen isotope composition during simulated and in situ early sedimentary diagenesis. Geochim Cosmochim Acta 66:3573-3584

Littler MM, Littler DS (1980) The evolution of thallus form and survival strategies in benthic marine macroalgae: field and laboratory tests of a functional form model. Am Nat:2544

Lubchenco J (1978) Plant species diversity in a marine intertidal community: importance of herbivore food preference and algal competitive abilities. Am Nat:23-39

McMeans BC, McCann KS, Humphries M, Rooney N, Fisk AT (2015) Food web structure in temporally-forced ecosystems. Trends Ecol Evol 30:662-672

Migné A, Golléty C, Davoult D (2015) Effect of canopy removal on a rocky shore community metabolism and structure. Mar Biol 162:449-457

Miller RJ, Page HM (2012) Kelp as a trophic resource for marine suspension feeders: a review of isotope-based evidence. Mar Biol 159:1391-1402

Molis M, Koerner J, Ko YW, Kim JH, Wahl M (2006) Inducible responses in the brown seaweed Ecklonia cava: the role of grazer identity and season. J Ecol 94:243-249

Nordström M, Aarnio K, Bonsdorff E (2009) Temporal variability of a benthic food web: patterns and processes in a low-diversity system. Mar Ecol Prog Ser 378:13-26 
Norton TA, Hawkins SJ, Manley NL, Williams GA, Watson DC (1990) Scraping a living: a review of littorinid grazing. In: Johannesson K, Raffaelli DG, Ellis CJH (eds) Progress in Littorinid and Muricid Biology. Springer Netherlands, p 117-138

Ouisse V, Riera P, Migné A, Leroux C, Davoult D (2011) Food web analysis in intertidal Zostera marina and Zostera noltii communities in winter and summer. Mar Biol 159:165-175

Parnell AC, Inger R, Bearhop S, Jackson AL (2010) Source partitioning using stable isotopes: coping with too much variation. PLoS ONE 5:e9672

Parnell A, Jackson A (2013) Stable Isotope Analysis in R.

Peterson BJ, Fry B (1987) Stable isotopes in ecosystem studies. Annu Rev Ecol Syst 18:293320

Phillips DL, Inger R, Bearhop S, Jackson AL, Moore JW, Parnell AC, Semmens BX, Ward EJ (2014) Best practices for use of stable isotope mixing models in food-web studies. Can J Zool 92:823-835

Post DM (2002) Using stable isotopes to estimate trophic position: models, methods, and assumptions. Ecology 83:703-718

R Core Team (2015) R: A Language and Environment for Statistical Computing. R Foundation for Statistical Computing, Vienna, Austria

Raffaelli DG, Hawkins SJ (1999) Intertidal ecology. Kluwer Academic Publishers

Raven JA, Hurd CL (2012) Ecophysiology of photosynthesis in macroalgae. Photosynth Res $113: 105-125$

Ricciardi A, Bourget E (1999) Global patterns of macroinvertebrate biomass in marine intertidal communities. Mar Ecol Prog Ser 185:21-35 
550 Riera P, Escaravage C, Leroux C (2009) Trophic ecology of the rocky shore community associated with the Ascophyllum nodosum zone (Roscoff, France): A $\delta^{13} \mathrm{C}$ vs $\delta^{15} \mathrm{~N}$ investigation. Estuar Coast Shelf Sci 81:143-148

Rigolet C, Thiébaut E, Brind'Amour A, Dubois SF (2015) Investigating isotopic functional indices to reveal changes in the structure and functioning of benthic communities. Funct Ecol 29:1350-1360

Rindi F, Guiry MD (2004) Composition and spatio temporal variability of the epiphytic macroalgal assemblage of Fucus vesiculosus Linnaeus at Clare Island, Mayo, western Ireland. J Exp Mar Biol Ecol 311:233-252

Rio A, Cabioch J (1988) Apparition du Caulacanthus ustulatus (Rhodophyta, Gigartinales) dans la Manche occidentale. Cryptogam Algol 9:231-234

Rooney N, McCann KS, Moore JC (2008) A landscape theory for food web architecture. Ecol Lett 11:867-881

Sarà G, De Pirro M, Romano C, Rumolo P, Sprovieri M, Mazzola A (2007) Sources of organic matter for intertidal consumers on Ascophyllum-shores (SW Iceland): a multistable isotope approach. Helgol Mar Res 61:297-302

Schaal G, Riera P, Leroux C (2011) Microscale variations of food web functioning within a rocky shore invertebrate community. Mar Biol 158:623-630

Schaal G, Riera P, Leroux C, Grall J (2010) A seasonal stable isotope survey of the food web associated to a peri-urban rocky shore. Mar Biol 157:283-294

Schlacher TA, Connolly RM (2014) Effects of acid treatment on carbon and nitrogen stable isotope ratios in ecological samples: a review and synthesis. Methods Ecol Evol $5: 541-550$ 
573 Silva A, Hawkins S, Boaventura D, Brewster E, Thompson R (2010) Use of the intertidal zone by mobile predators: influence of wave exposure, tidal phase and elevation on abundance and diet. Mar Ecol Prog Ser 406:197-210

Smith JR, Vogt SC, Creedon F, Lucas BJ, Eernisse DJ (2014) The non-native turf-forming alga Caulacanthus ustulatus displaces space-occupants but increases diversity. Biol Invasions 16:2195-2208

Steinarsdóttir MB, Ingólfsson A, Ólafsson E (2009) Trophic relationships on a fucoid shore in south-western Iceland as revealed by stable isotope analyses, laboratory experiments, field observations and gut analyses. J Sea Res 61:206-215

Thompson RM, Hemberg M, Starzomski BM, Shurin JB (2007) Trophic levels and trophic tangles: the prevalence of omnivory in real food webs. Ecology 88:612-617

Underwood AJ (1984) Microalgal food and the growth of the intertidal gastropods Nerita atramentosa Reeve and Bembicium nanum (Lamarck) at four heights on a shore. J Exp Mar Biol Ecol 79:277-291

Vanderklift MA, Bearham D (2014) Variation in $\delta^{13} \mathrm{C}$ and $\delta^{15} \mathrm{~N}$ of kelp is explained by light and productivity. Mar Ecol Prog Ser 515:111-121

Viana IG, Bode A, Bartholomew M, Valiela I (2015) Experimental assessment of the macroalgae Ascophyllum nodosum and Fucus vesiculosus for monitoring $\mathrm{N}$ sources at different time-scales using stable isotope composition. J Exp Mar Biol Ecol 466:24-33

Wahl M (2009) Marine Hard Bottom Communities: Patterns, Dynamics, Diversity, and Change. Springer Science \& Business Media

Warry FY, Reich P, Woodland RJ, Thomson JR, Nally RM, Cook PLM (2016) Nitrogen stable isotope values of large-bodied consumers reflect urbanization of coastal catchments. Mar Ecol Prog Ser 542:25-37 
597 Watson DC, Norton TA (1985) Dietary preferences of the common periwinkle, Littorina $598 \quad$ littorea (L.). J Exp Mar Biol Ecol 88:193-211

599 Zanden MJV, Rasmussen JB (2001) Variation in $\delta^{15} \mathrm{~N}$ and $\delta^{13} \mathrm{C}$ trophic fractionation: 600 Implications for aquatic food web studies. Limnol Oceanogr 46:2061-2066 601 

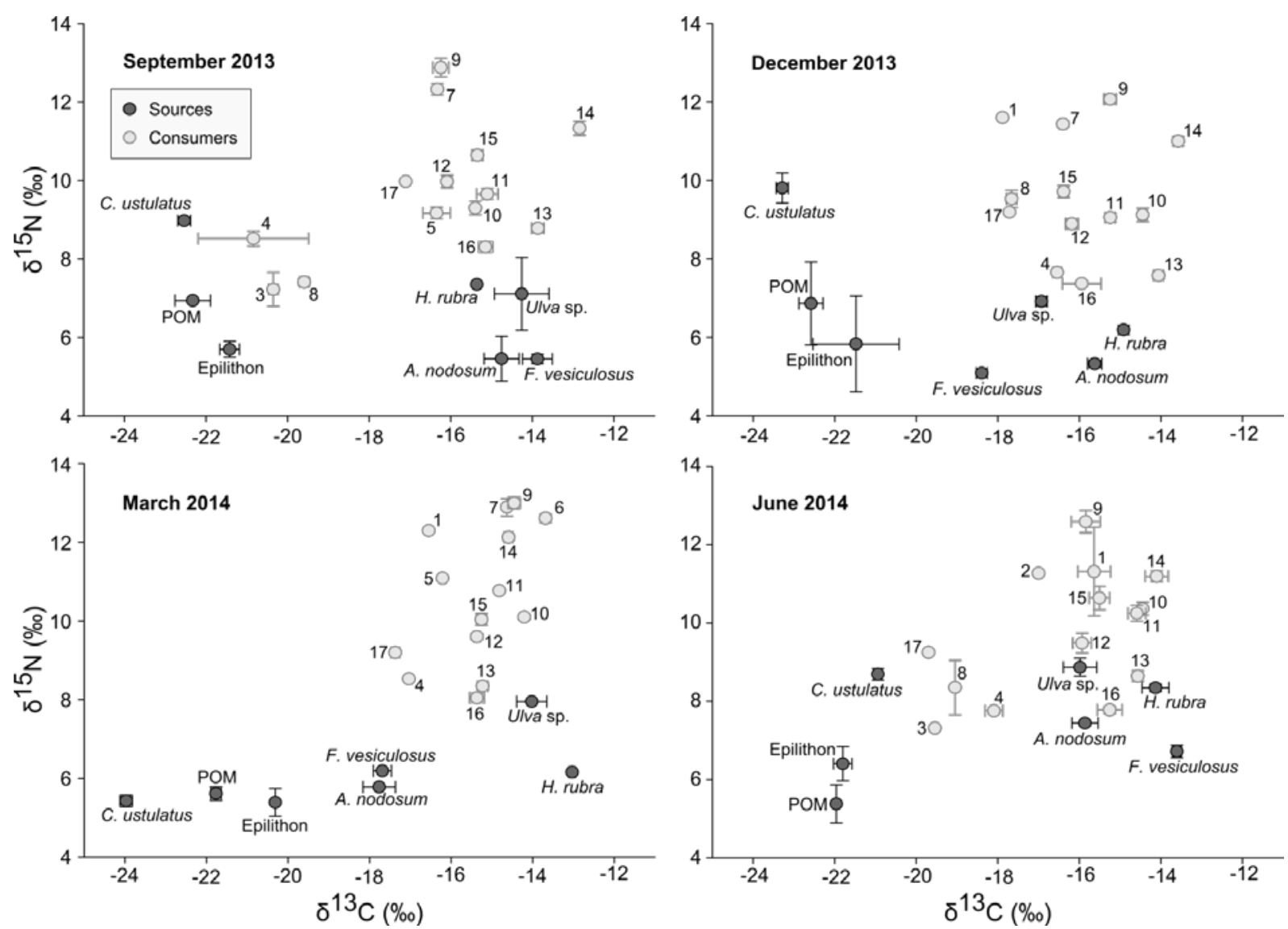

602

Figure 1: Mean \pm SE of $\delta^{15} \mathrm{~N}$ (\%) vs $\delta^{13} \mathrm{C}$ (\%) for primary producers and consumers of the

604 Fucus vesiculosus community, sampled in September and December 2013 and March and

605 June 2014. Sources are represented by dark-grey rounds and their names are indicated nearby,

606 while consumers are represented by light-grey rounds. Consumers : 1 Actinia equina; 2

607 Actinia fragacea; 3 Alcyonidium sp.; 4 Amphipods; 5 Anemonia viridis; 6 Asterina gibbosa; 7

608 Calliostoma zizyphinum; 8 Campanulariidae; 9 Carcinus maenas; 10 Gibbula pennanti; 11

609 Gibbula umbilicalis; 12 Littorina littorea; 13 Littorina obtusata; 14 Nucella lapillus; 15

610 Phorcus lineatus; 16 Patella vulgata; 17 Spirorbis sp. Values are given in Supplementary

611 Material 1. 

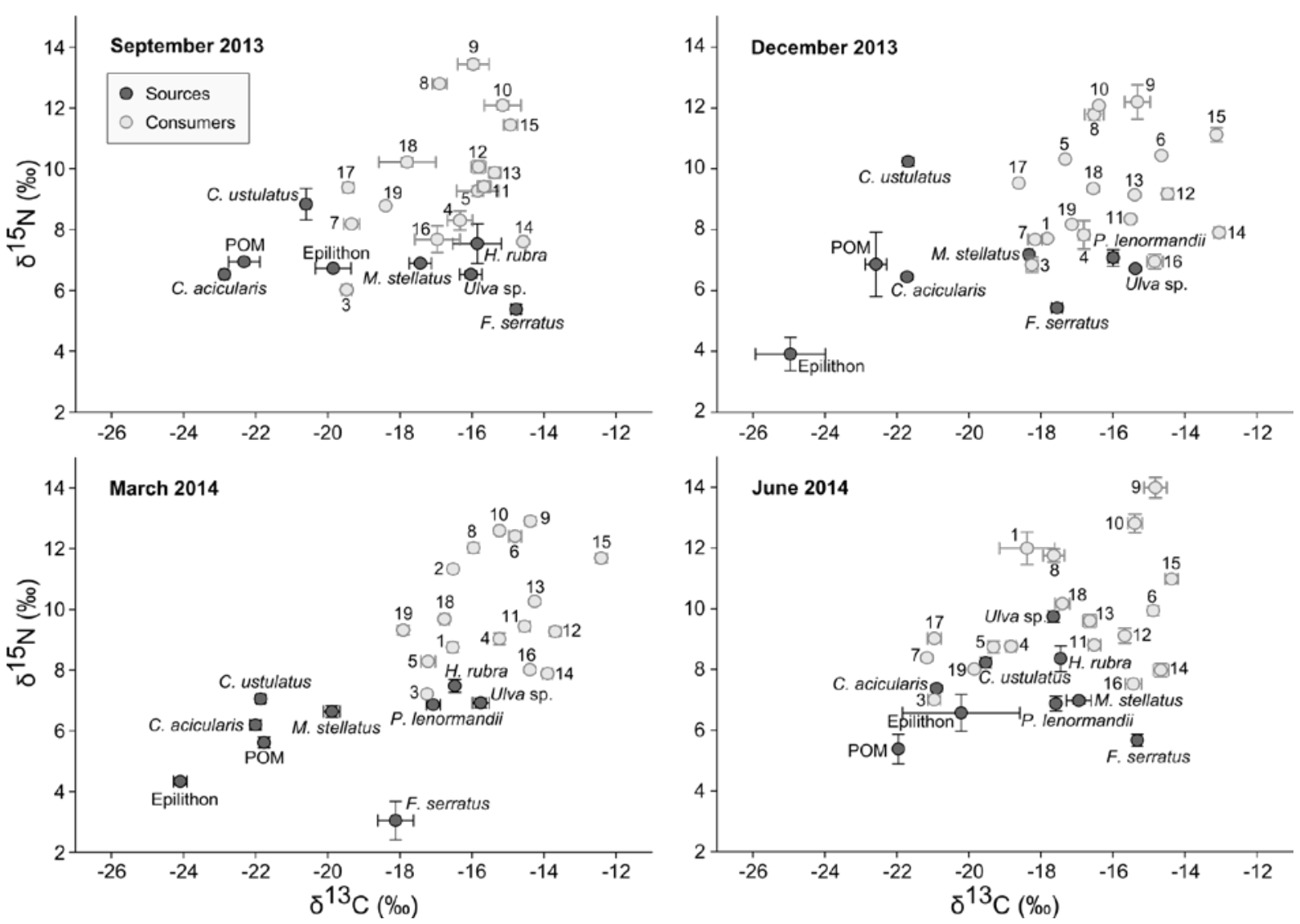

614 Figure 2: Mean \pm SE of $\delta^{15} \mathrm{~N}(\%)$ vs $\delta^{13} \mathrm{C}$ (\%) for primary producers and consumers of the

615 Fucus serratus community, sampled in September and December 2013 and March and June

616 2014. Sources are represented by dark-grey rounds and their names are indicated nearby, 617 while consumers are represented by light-grey rounds. Consumers : 1 Actinia equina; 2 618 Actinia fragacea; 3 Alcyonidium sp.; 4 Amphipods; 5 Anemonia viridis; 6 Asterina gibbosa; 7 619 Botryllus schlosseri; 8 Calliostoma zizyphinum; 9 Cancer pagurus; 10 Carcinus maenas; 11 620 Gibbula cineraria; 12 Gibbula pennanti; 13 Gibbula umbilicalis; 14 Littorina obtusata; 15

621 Nucella lapillus; 16 Patella vulgata; 17 Polyclinidae; 18 Porcellana platycheles;

62219 Spirorbis sp. Values are given in Supplementary Material 2. 


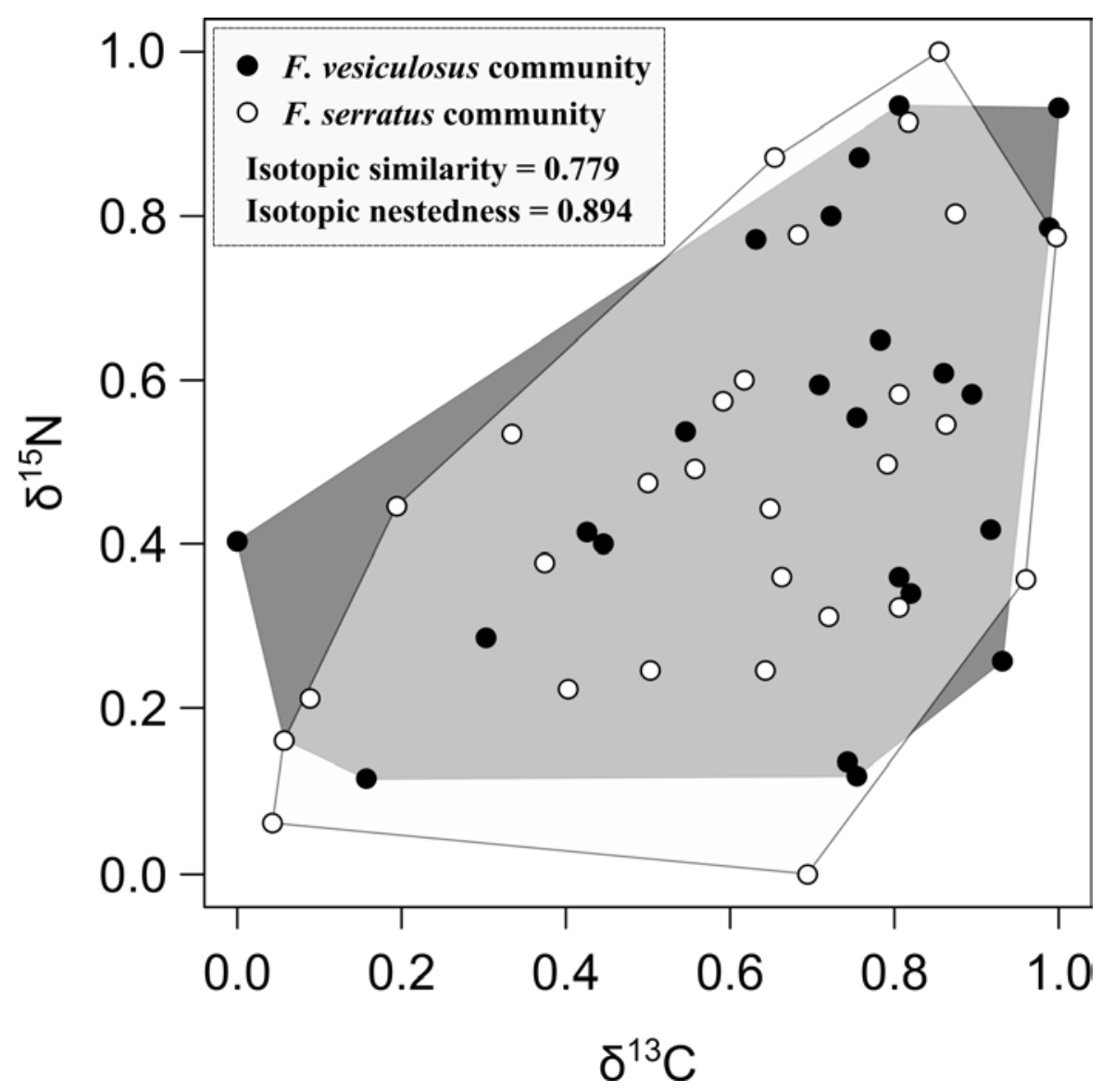

625 Figure 3: Annual mean of scaled $\delta^{15} \mathrm{~N}$ vs scaled $\delta^{13} \mathrm{C}$ for primary producers and consumers of

626 the F. vesiculosus (black rounds) and F. serratus (white rounds) communities. Isotopic spaces

627 are represented in dark-grey for the F. vesiculosus community and in white for the F. serratus

628 community. The light-grey space represents the intersection of these two isotopic spaces. 


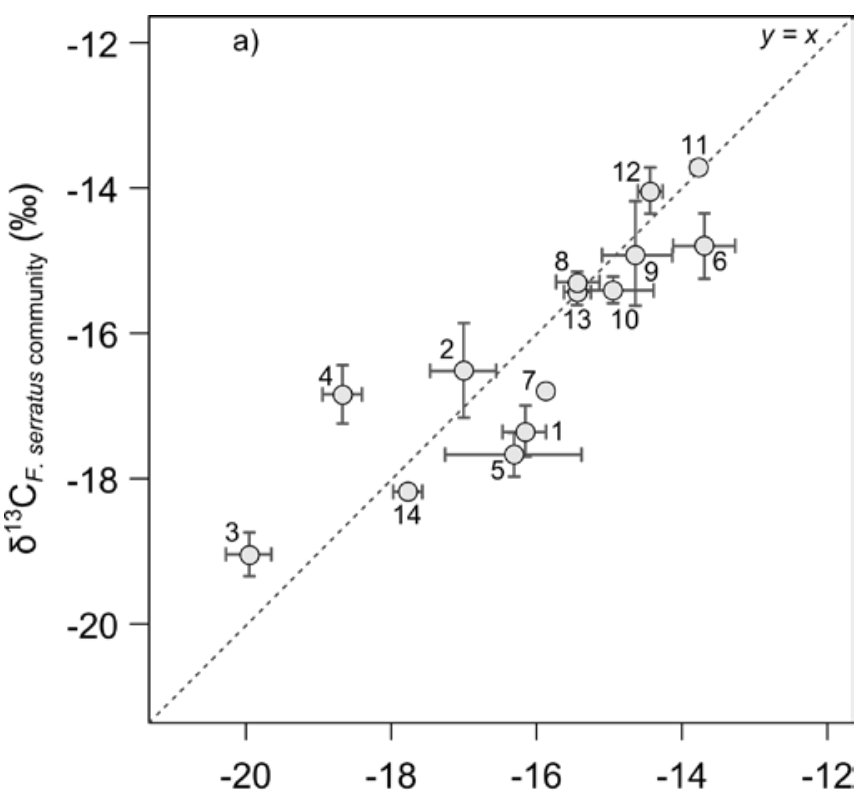

630

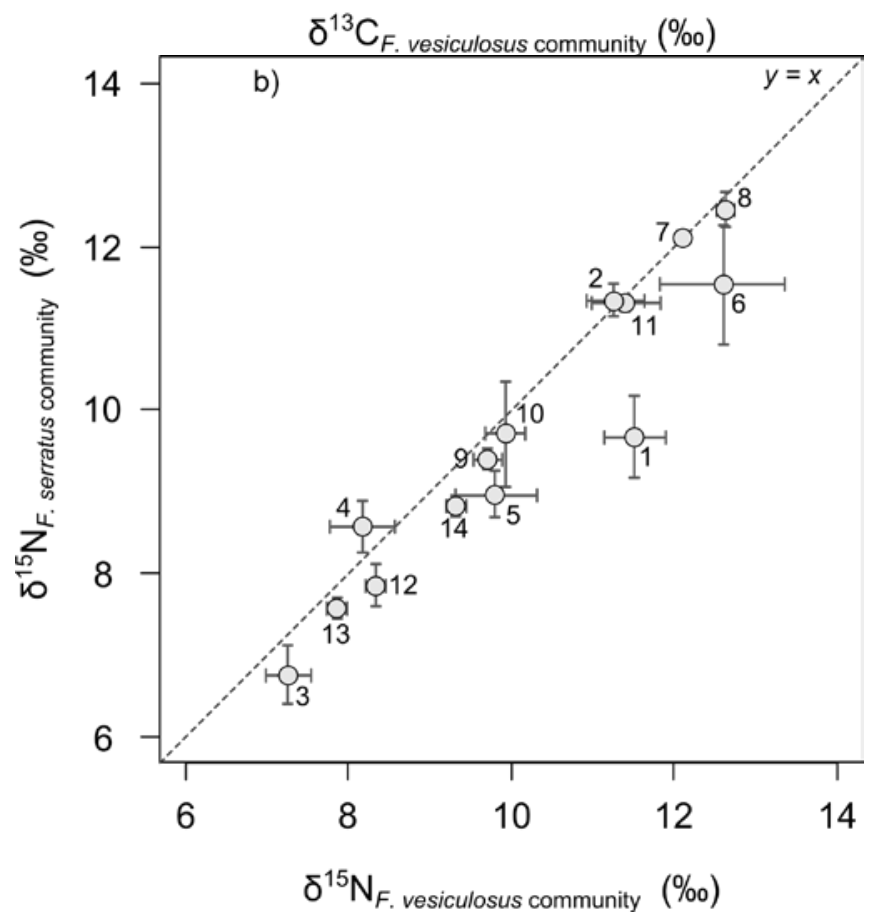

Figure 4: Annual mean of a) $\delta^{13} \mathrm{C} \pm \mathrm{SE}$ (\%) of shared taxa obtained in the F. vesiculosus

633 community vs those obtained in the F. serratus community, and of b) $\delta^{15} \mathrm{~N} \pm \mathrm{SE}$ (\%) of 634 shared taxa obtained in the F. vesiculosus community vs those obtained in the F. serratus 635 community. Dashed lines represent the function $\mathrm{f}(\mathrm{x})=\mathrm{y}$. Shared taxa: 1 Actinia equina; 2 636 Actinia fragacea; 3 Alcyonidium sp.; 4 Amphipods; 5 Anemonia viridis; 6 Asterina gibbosa; 7 637 Calliostoma zizyphinum; 8 Carcinus maenas; 9 Gibbula pennanti; 10 Gibbula umbilicalis; 11 638 Nucella lapillus; 12 Littorina obtusata; 13 Patella vulgata; 14 Spirorbis sp. 

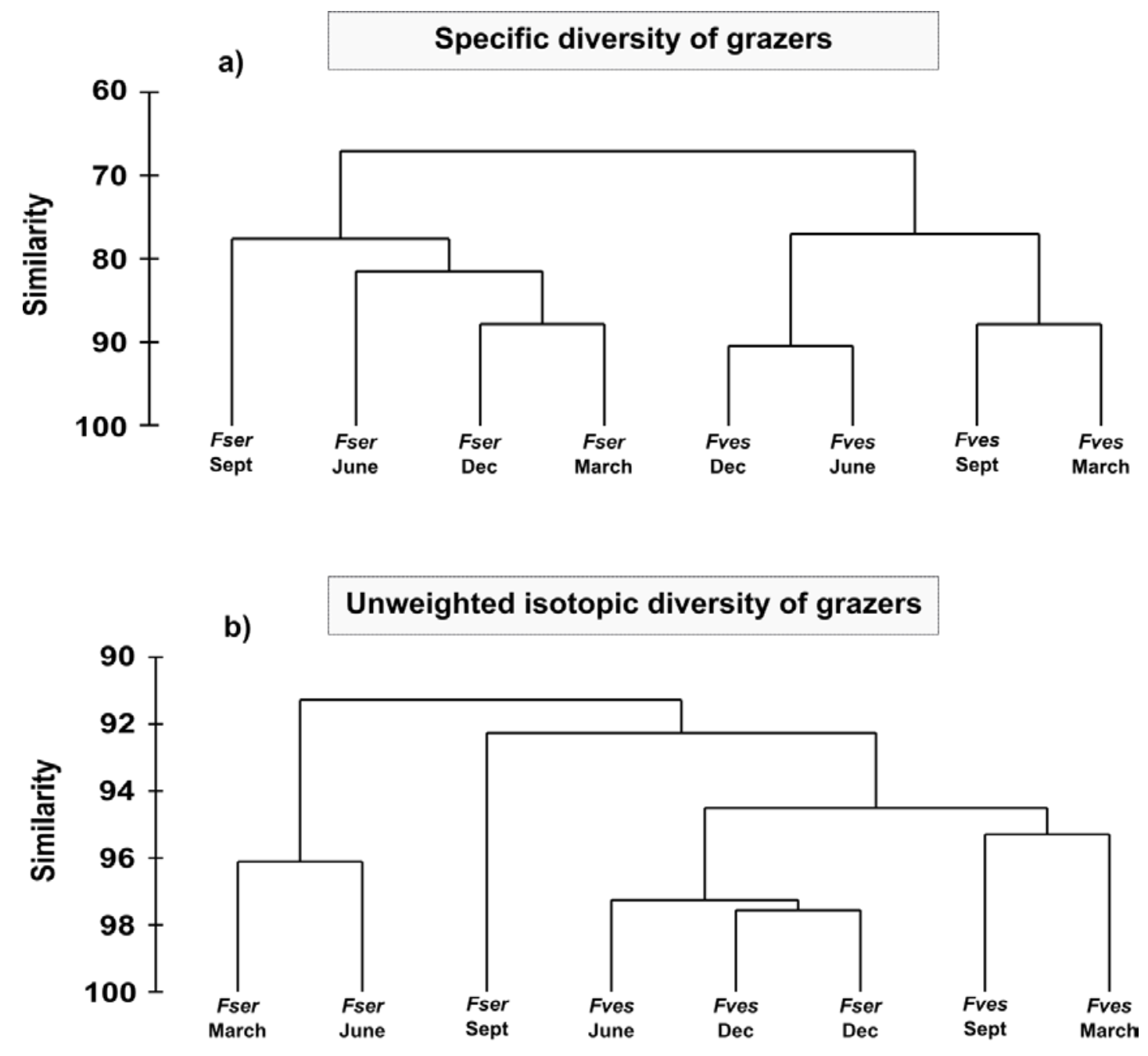

Unweighted isotopic diversity of grazers

c)

Weighted isotopic diversity of grazers

640 Figure 5: Dendrograms from clustering analyses conducted on the grazers' data; a) on square-

641 root transformed abundances, b) on isotopic diversity metrics calculated from unweighted

642 isotopic data, and c) on isotopic diversity metrics calculated from isotopic data weighted by

643 grazers’ abundances. 
644 Table 1: Isotopic diversity metrics calculated at each season and for each community, and

645 their associated coefficient of variation (CV, in \%).

\begin{tabular}{clccccc} 
& \multicolumn{1}{c}{ Date } & Sept & Dec & March & June & CV \\
\cline { 2 - 7 } & Isotopic richness & 0.590 & 0.565 & 0.528 & 0.413 & 13.3 \\
\multirow{2}{*}{$\begin{array}{c}\text { F. vesiculosus } \\
\text { community }\end{array}$} & Isotopic divergence & 0.765 & 0.729 & 0.695 & 0.743 & 3.8 \\
& Isotopic dispersion & 0.607 & 0.535 & 0.429 & 0.461 & 13.1 \\
& Isotopic eveness & 0.785 & 0.791 & 0.774 & 0.844 & 4.0 \\
& Isotopic uniqueness & 0.455 & 0.349 & 0.394 & 0.500 & 14.6
\end{tabular}

646

\begin{tabular}{lccccc}
\multicolumn{1}{c}{ Date } & Sept & Dec & March & June & CV \\
\hline Isotopic richness & 0.269 & 0.415 & 0.389 & 0.308 & 25.4 \\
Isotopic divergence & 0.709 & 0.701 & 0.681 & 0.722 & 2.4 \\
Isotopic dispersion & 0.503 & 0.334 & 0.400 & 0.447 & 14.3 \\
Isotopic eveness & 0.828 & 0.737 & 0.743 & 0.801 & 5.4 \\
Isotopic uniqueness & 0.538 & 0.274 & 0.249 & 0.425 & 25.2
\end{tabular}


648 Table 2: Ranges ( $1^{\text {st }}-99^{\text {th }}$ percentiles) and mean of potential contributions (\%) of primary 649 sources to the diet of several species of filter-feeders and grazers, according to SIAR mixing 650 models. Analyses were carried out for each community and during all sampling seasons. 


\section{F. vesiculosus community}

\begin{tabular}{|c|c|c|c|c|c|c|}
\hline & Date & A. nodosum & F. vesiculosus & C. ustulatus & Epilithon & Ulva spp. \\
\hline \multicolumn{7}{|l|}{ Filter-feeders } \\
\hline \multirow[t]{3}{*}{ Campanulariidae } & September & $0.2-32.2(12.3)$ & $0.2-28.3(10.9)$ & $2.3-62.5(31.5)$ & $5.7-67.5(36.2)$ & $0.2-28.3(9.2)$ \\
\hline & December & $1.9-55.9(28.2)$ & $0.3-45.1(15.6)$ & $0.6-33.6(14.7)$ & $0.2-29.9(8.8)$ & $2.6-69.4(32.8)$ \\
\hline & June & $0.3-36.5(13.4)$ & $0.3-27.8(10.9)$ & $0.8-56.2(24.9)$ & $11.7-63.8(39.4)$ & $0.2-34.4(11.5)$ \\
\hline \multirow[t]{4}{*}{ Spirorbis sp. } & September & $0.6-45.4(19.0)$ & $0.7-43.1(19.1)$ & $1.2-40.5(21.5)$ & $0.5-39.8(17.2)$ & $1.6-47.3(23.3)$ \\
\hline & December & $3.4-57.2(29.9)$ & $0.5-46.3(18.6)$ & $0.4-25.7(11.4)$ & $0.2-28.9(9.7)$ & $2.4-61.5(30.5)$ \\
\hline & March & $0.7-47.1(20.6)$ & $0.9-52.5(23.1)$ & $0.3-28.2(10.7)$ & $0.3-34.1(13.1)$ & $14.1-50.8(32.5)$ \\
\hline & June & $0.2-46.5(14.4)$ & $1.4-39.0(23.3)$ & $0.1-20.5(5.6)$ & $36.3-59.7(49.4)$ & $0.1-29.6(7.3)$ \\
\hline \multicolumn{7}{|l|}{ Grazers } \\
\hline \multirow[t]{4}{*}{ Gibbula umbilicalis } & September & $0.5-50.3(19.8)$ & $1.0-51.8(24.3)$ & $0.7-32.4(12.2)$ & $0.1-20.6(5.9)$ & $10.1-64.2(37.7)$ \\
\hline & December & $3.2-64.5(30.5)$ & $0.3-41.0(15.5)$ & $0.4-28.8(12.7)$ & $0.1-.30 .0(8.1)$ & $3.1-67.7(33.1)$ \\
\hline & March & $0.1-23.5(6.6)$ & $0.1-26.4(8.1)$ & $0.1-10.6(3.3)$ & $0.1-15.3(4.4)$ & $63.0-89.3(77.6)$ \\
\hline & June & $0.4-52.7(18.5)$ & $14.3-71.3(44.4)$ & $0.1-22.5(4.9)$ & $0.1-15.6(3.3)$ & $2.3-53.5(28.9)$ \\
\hline \multirow[t]{4}{*}{ Littorina obtusata } & September & $0.5-47.3(17.8)$ & $17.9-77.3(48.7)$ & $0.1-7.8(2.0)$ & $0.1-7.4(1.9)$ & $8.7-51.1(29.6)$ \\
\hline & December & $20.1-94.4(67.6)$ & $0.4-64.9(21.1)$ & $0.1-5.8(1.4)$ & $0.1-21.4(4.5)$ & $0.1-20.4(5.4)$ \\
\hline & March & $0.5-57.2(20.4)$ & $0.3-45.6(15.9)$ & $0.1-26.6(4.2)$ & $0.1-38.0(9.0)$ & $2.0-76.4(50.5)$ \\
\hline & June & $0.2-41.7(12.8)$ & $49.1-84.2(71.2)$ & $0.1-12.7(3.5)$ & $0.3-15.1(7.3)$ & $0.1-24.3(5.2)$ \\
\hline \multirow[t]{4}{*}{ Patella vulgata } & September & $2.1-58.6(28.4)$ & $8.5-68.5(38.1)$ & $0.1-15.5(5.8)$ & $0.5-22.8(10.6)$ & $0.7-41.4(17.1)$ \\
\hline & December & $9.2-86.7(52.3)$ & $0.8-70.0(27.8)$ & $0.1-11.8(2.4)$ & $0.1-32.5(7.9)$ & $0.1-41.9(9.6)$ \\
\hline & March & $0.6-59.2(23.3)$ & $0.5-50.8(19.7)$ & $0.1-43.3(12.0)$ & $0.2-51.0(18.0)$ & $0.3-73.5(27.0)$ \\
\hline & June & $0.6-60.1(25.0)$ & $13.8-72.2(42.9)$ & $0.1-24.1(6.8)$ & $0.2-26.6(8.6)$ & $0.3-49.2(16.7)$ \\
\hline
\end{tabular}

\section{F. serratus community}

\begin{tabular}{|c|c|c|c|c|c|c|}
\hline & Date & F. serratus & C. ustulatus \& $C$. acicularis & M. stellatus & Epilithon & Ulva spp. \\
\hline \multicolumn{7}{|l|}{ Filter-feeders } \\
\hline \multirow[t]{4}{*}{ Alcyonidium sp. } & September & $0.2-27.3(9.5)$ & $0.8-56.2(23.9)$ & $0.4-42.5(16.1)$ & $15.2-60.2(39.2)$ & $0.2-32.2(11.2)$ \\
\hline & December & $1.5-66.7(28.1)$ & $0.2-35.2(13.1)$ & $0.5-49.2(19.5)$ & $0.6-35.4(16.1)$ & $1.2-45.0(23.3)$ \\
\hline & March & $8.5-61.5(41.2)$ & $0.1-17.3(5.0)$ & $0.1-27.3(8.2)$ & $0.1-21.5(6.1)$ & $17.4-61.2(39.5)$ \\
\hline & June & $01-18.2(4.2)$ & $0.1-39.1(9.7)$ & $0.1-20.1(4.7)$ & $36.5-91.9(77.6)$ & $0.1-16.8(3.8)$ \\
\hline \multirow[t]{4}{*}{ Spirorbis sp. } & September & $0.9-40.8(19.7)$ & $0.4-39.4(15.4)$ & $0.4-47.4(18.2)$ & $10.8-46.7(29.5)$ & $0.4-44.1(17.2)$ \\
\hline & December & $2.4-75.5(37.4)$ & $0.1-21.7(6.2)$ & $0.2-43.8(14.1)$ & $0.1-21.5(6.7)$ & $8.6-62.9(35.7)$ \\
\hline & March & $0.2-36.7(9.3)$ & $0.3-37.2(13.1)$ & $0.6-51.6(22.3)$ & $0.2-32.8(10.5)$ & $19.3-61.8(44.9)$ \\
\hline & June & $0.3-27.6(11.0)$ & $0.3-49.1(16.1)$ & $0.2-36.3(12.0)$ & $29.9-73.3(54.1)$ & $0.1-25.3(6.9)$ \\
\hline \multicolumn{7}{|l|}{ Grazers } \\
\hline \multirow[t]{4}{*}{ Gibbula pennanti } & September & $1.1-62.5(29.4)$ & $0.2-45.1(12.7)$ & $0.4-48.4(18.9)$ & $0.1-30.8(7.7)$ & $1.5-76.1(31.4)$ \\
\hline & December & $0.5-45.4(18.9)$ & $0.2-33.1(10.7)$ & $0.5-53.6(22.4)$ & $0.1-23.5(5.6)$ & $4.8-88.2(42.5)$ \\
\hline & March & $0.1-20.0(4.9)$ & $2.7-50.9(17.4)$ & $0.5-57.8(23.1)$ & $0.1-20.7(5.0)$ & $10.6-87.4(49.6)$ \\
\hline & June & $45.2-83.1(69.2)$ & $0.1-11.5(3.1)$ & $0.3-42.2(13.6)$ & $0.1-10.7(2.6)$ & $0.4-26.3(11.5)$ \\
\hline \multirow[t]{4}{*}{ Littorina obtusata } & September & 76.6 - $97.1(89.9)$ & $0.1-4.3(1.1)$ & $0.1-9.7(2.5)$ & $0.1-6.0(1.5)$ & $0.1-18.1(5.0)$ \\
\hline & December & $7.3-74.8(37.8)$ & $0.1-14.3(3.6)$ & $0.2-31.5(10.1)$ & $3.0-44.8(26.4)$ & $1.2-46.1(22.1)$ \\
\hline & March & $9.3-41.5(26.2)$ & $0.2-34.0(12.3)$ & $0.5-39.9(16.8)$ & $0.3-38.8(15.7)$ & $5.8-57.9(30.0)$ \\
\hline & June & $60.8-96.9(86.3)$ & $0.1-10.5(2.3)$ & $0.1-28.4(6.0)$ & $0.1-13.0(2.9)$ & $0.1-10.6(2.5)$ \\
\hline \multirow[t]{4}{*}{ Patella vulgata } & September & $2.3-55.9(27.1)$ & $0.2-35.4(12.1)$ & $0.4-48.2(19.5)$ & $0.6-45.6(20.0)$ & $0.7-50.5(21.3)$ \\
\hline & December & $1.1-64.8(27.6)$ & $0.1-34.7(9.1)$ & $0.3-45.3(15.6)$ & $0.3-64.2(20.4)$ & $0.7-79.2(27.4)$ \\
\hline & March & $3.9-40.1(22.4)$ & $0.4-38.9(15.6)$ & $0.6-43.4(18.9)$ & $0.3-41.2(16.1)$ & $2.9-57.3(27.0)$ \\
\hline & June & $35.9-93.3(76.7)$ & $0.1-17 . .0(3.8)$ & $0.2-42.8(10.3)$ & $0.1-22.2(5.0)$ & $0.1-20.5(4.2)$ \\
\hline
\end{tabular}


653 Table 3: Abundance of grazers recorded at each period of observation in the two

654 communities.

\begin{tabular}{clcccc} 
& Date & Sept & Dec & March & June \\
\cline { 2 - 6 } & Gibbula cineraria & 0 & 2 & 0 & 2 \\
& Gibbula pennanti & 58 & 170 & 32 & 226 \\
F. vesiculosus & Gibbula umbilicalis & 208 & 106 & 174 & 96 \\
& Littorina littorea & 6 & 12 & 16 & 2 \\
& Littorina obtusata & 172 & 76 & 118 & 86 \\
& Littorina saxatilis & 4 & 0 & 0 & 0 \\
& Patella vulgata & 32 & 62 & 20 & 22 \\
& & & & & \\
& Date & & & & \\
& Gibbula cineraria & Sept & Dec & March & June \\
\cline { 2 - 6 } community & Gibbula pennanti & 130 & 430 & 508 & 240 \\
& Gibbula umbilicalis & 36 & 38 & 24 & 46 \\
& Lamellaria perspicua & 0 & 4 & 0 & 0 \\
& Littorina obtusata & 94 & 80 & 70 & 18 \\
& Patella vulgata & 2 & 12 & 36 & 32 \\
& Tricolia pullus & 0 & 0 & 2 & 0
\end{tabular}


Supplementary material 1: Mean \pm SE (\%o) of $\delta^{13} \mathrm{C}$ and $\delta^{15} \mathrm{~N}$ of sources and consumers of the F. vesiculosus community, with the number of replicates (n) analysed for each sampling period (September and December 2013 and March and June 2014). Groups: ER = Erect alga; EN = Encrusting alga; G = Grazer;

FF $=$ Filter-feeder; $\mathrm{P}=$ Predator.

\begin{tabular}{|c|c|c|c|c|c|c|c|c|c|c|c|c|c|}
\hline & \multirow[b]{2}{*}{ Group } & \multicolumn{3}{|c|}{ September } & \multicolumn{2}{|c|}{ December } & \multicolumn{4}{|c|}{ March } & \multicolumn{3}{|c|}{ June } \\
\hline & & $\delta^{13} \mathrm{C}(\%)$ & $\delta^{15} \mathrm{~N}(\%)$ & $\mathrm{n}$ & $\delta^{13} \mathrm{C}(\%)$ & $\delta^{15} \mathrm{~N}(\%)$ & $\mathrm{n}$ & $\delta^{13} \mathrm{C}(\%)$ & $\delta^{15} \mathrm{~N}(\%)$ & $\mathrm{n}$ & $\delta^{13} \mathrm{C}(\%)$ & $\delta^{15} \mathrm{~N}(\%)$ & $n$ \\
\hline \multicolumn{14}{|l|}{ Sources } \\
\hline Ascophyllum nodosum & ER & $-14.8 \pm 0.4$ & $5.5 \pm 0.6$ & 3 & $-15.6 \pm 0.2$ & $5.3 \pm 0.1$ & 3 & $-17.8 \pm 0.4$ & $5.8 \pm 0.1$ & 3 & $-15.9 \pm 0.3$ & $7.4 \pm 0.1$ & 3 \\
\hline Caulacanthus ustulatus & ER & $-22.5 \pm 0.2$ & $9.0 \pm 0.1$ & 3 & $-23.3 \pm 0.1$ & $9.8 \pm 0.4$ & 3 & $-24.0 \pm 0.2$ & $5.4 \pm 0.1$ & 3 & $-20.9 \pm 0.1$ & $8.7 \pm 0.1$ & 3 \\
\hline Fucus vesiculosus & ER & $-13.9 \pm 0.4$ & $5.5 \pm 0.1$ & 3 & $-18.4 \pm 0.1$ & $5.1 \pm 0.1$ & 3 & $-17.7 \pm 0.2$ & $6.2 \pm 0.1$ & 3 & $-13.6 \pm 0.1$ & $6.7 \pm 0.2$ & 3 \\
\hline Hildenbrandia rubra & EN & -15.4 & 7.4 & 1 & $-14.9 \pm 0.1$ & $6.2 \pm 0.2$ & 3 & $-13.0 \pm 0.1$ & $6.2 \pm 0.1$ & 2 & $-14.1 \pm 0.3$ & $8.3 \pm 0.1$ & 3 \\
\hline Ulva sp. & ER & $-14.3 \pm 0.7$ & $7.1 \pm 0.9$ & 3 & $-16.9 \pm 0.1$ & $6.9 \pm 0.1$ & 3 & $-14.0 \pm 0.4$ & $7.9 \pm 0.1$ & 3 & $-16.0 \pm 0.4$ & $8.9 \pm 0.2$ & 3 \\
\hline Epilithon & & $-21.4 \pm 0.2$ & $5.7 \pm 0.2$ & 2 & $-21.5 \pm 1.1$ & $5.8 \pm 1.2$ & 2 & $-20.3 \pm 0.1$ & $5.4 \pm 0.4$ & 2 & $-21.8 \pm 0.2$ & $6.4 \pm 0.4$ & 2 \\
\hline POM & & $-22.3 \pm 0.4$ & $6.9(1)$ & 2 & $-22.6 \pm 0.3$ & $6.9 \pm 1.1$ & 3 & $-21.8 \pm 0.1$ & $5.6 \pm 0.2$ & 3 & $-22.0(1)$ & $5.4 \pm 0.5$ & 2 \\
\hline \multicolumn{14}{|l|}{ Cnidaria } \\
\hline Actinia equina & $P$ & & & & -17.9 & 11.6 & 1 & -16.5 & 12.3 & 1 & $-15.6 \pm 0.4$ & $11.3 \pm 1.1$ & 4 \\
\hline Actinia fragacea & $P$ & & & & & & & & & & -17.0 & 11.3 & 1 \\
\hline Anemonia viridis & $P$ & $-16.3 \pm 0.3$ & $9.2 \pm 0.1$ & 2 & & & & -16.2 & 11.1 & 1 & & & \\
\hline Campanulariidae & $\mathrm{FF}$ & $-19.6 \pm 0.1$ & $7.4 \pm 0.1$ & 4 & $-17.7 \pm 0.1$ & $9.5 \pm 0.2$ & 3 & & & & $-19.0 \pm 0.1$ & $8.4 \pm 0.7$ & 3 \\
\hline \multicolumn{14}{|l|}{ Annelida } \\
\hline Spirorbis sp. & $\mathrm{FF}$ & -17.1 & 10.0 & 1 & -17.7 & 9.2 & 1 & $-17.4 \pm 0.1$ & $9.2 \pm 0.1$ & 3 & -19.7 & 9.3 & 1 \\
\hline \multicolumn{14}{|l|}{ Mollusca } \\
\hline Calliostoma zizyphinum & $\mathrm{P}$ & $-16.3 \pm 0.1$ & $12.3 \pm 0.1$ & 2 & $-16.4 \pm 0.1$ & $11.4 \pm 0.1$ & 3 & $-14.6 \pm 0.1$ & $12.9 \pm 0.2$ & 2 & & & \\
\hline Gibbula pennanti & G & $-15.4 \pm 0.1$ & $9.3 \pm 0.2$ & 6 & $-14.4 \pm 0.1$ & $9.1 \pm 0.2$ & 6 & $-14.2 \pm 0.1$ & $10.1 \pm 0.1$ & 6 & $-14.5 \pm 0.1$ & $10.4 \pm 0.2$ & 6 \\
\hline Gibbula umbilicalis & G & $-15.1 \pm 0.3$ & $9.7 \pm 0.1$ & 6 & $-15.2 \pm 0.1$ & $9.1 \pm 0.1$ & 6 & $-14.8 \pm 0.1$ & $10.8 \pm 0.1$ & 6 & $-14.6 \pm 0.2$ & $10.2 \pm 0.2$ & 6 \\
\hline Littorina littorea & G & $-16.1 \pm 0.1$ & $10.0 \pm 0.2$ & 6 & $-16.2 \pm 0.2$ & $8.9 \pm 0.1$ & 6 & $-15.4 \pm 0.1$ & $9.6 \pm 0.1$ & 6 & $-15.9 \pm 0.2$ & $9.5 \pm 0.2$ & 6 \\
\hline Littorina obtusata & G & $-13.9 \pm 0.2$ & $8.8 \pm 0.1$ & 10 & $-14.1 \pm 0.1$ & $7.6 \pm 0.1$ & 10 & $-15.2 \pm 0.1$ & $8.3 \pm 0.1$ & 10 & $-14.6 \pm 0.1$ & $8.6 \pm 0.1$ & 10 \\
\hline Nucella lapillus & $P$ & $-12.8 \pm 0.1$ & $11.3 \pm 0.2$ & 6 & $-13.6 \pm 0.1$ & $11.0 \pm 0.1$ & 6 & $-14.6 \pm 0.1$ & $12.1 \pm 0.1$ & 6 & $-14.1 \pm 0.3$ & $11.2 \pm 0.1$ & 6 \\
\hline Patella vulgata & G & $-15.1 \pm 0.2$ & $8.3 \pm 0.1$ & 6 & $-15.9 \pm 0.5$ & $7.4 \pm 0.1$ & 6 & $-15.4 \pm 0.2$ & $8.0 \pm 0.1$ & 5 & $-15.3 \pm 0.3$ & $7.8 \pm 0.1$ & 6 \\
\hline Phorcus lineatus & G & $-15.3 \pm 0.1$ & $10.6 \pm 0.1$ & 6 & $-16.4 \pm 0.1$ & $9.7 \pm 0.2$ & 6 & $-15.3 \pm 0.1$ & $10.0 \pm 0.2$ & 6 & $-15.5 \pm 0.2$ & $10.6 \pm 0.3$ & 6 \\
\hline \multicolumn{14}{|l|}{ Ectoprocta } \\
\hline Alcyonidium sp. & $\mathrm{FF}$ & $-20.3 \pm 0.1$ & $7.2 \pm 0.4$ & 6 & & & & & & & $-19.5 \pm 0.1$ & $7.3 \pm 0.1$ & 6 \\
\hline \multicolumn{14}{|l|}{ Arthropoda } \\
\hline Amphipods & $\mathrm{FF}$ & $-20.8 \pm 1.4$ & $8.5 \pm 0.2$ & 6 & $-16.5 \pm 0.1$ & $7.7 \pm 0.1$ & 3 & $-17.0 \pm 0.1$ & $8.5 \pm 0.1$ & 3 & $-18.1 \pm 0.2$ & $7.8 \pm 0.1$ & 3 \\
\hline Carcinus maenas & $P$ & $-16.2 \pm 0.2$ & $12.9 \pm 0.2$ & 5 & $-15.2 \pm 0.2$ & $12.1 \pm 0.1$ & 5 & $-14.5 \pm 0.2$ & $13.0 \pm 0.1$ & 5 & $-15.8 \pm 0.4$ & $12.6 \pm 0.3$ & 4 \\
\hline \multirow{2}{*}{\multicolumn{14}{|c|}{$\begin{array}{l}\text { Echinodermata } \\
\text { Asterina gibbosa }\end{array}$}} \\
\hline & $P$ & & & & & & & $-13.7 \pm 0.1$ & $12.6 \pm 0.1$ & 2 & & & \\
\hline
\end{tabular}


Supplementary material 2: Mean \pm SE (\%o) of $\delta^{13} \mathrm{C}$ and $\delta^{15} \mathrm{~N}$ of sources and consumers of the F. serratus community, with the number of replicates (n) analysed for each sampling period (September and December 2013 and March and June 2014). Groups: ER = Erect alga; EN = Encrusting alga; G = Grazer; FF $=$ Filter-feeder; $\mathrm{P}=$ Predator.

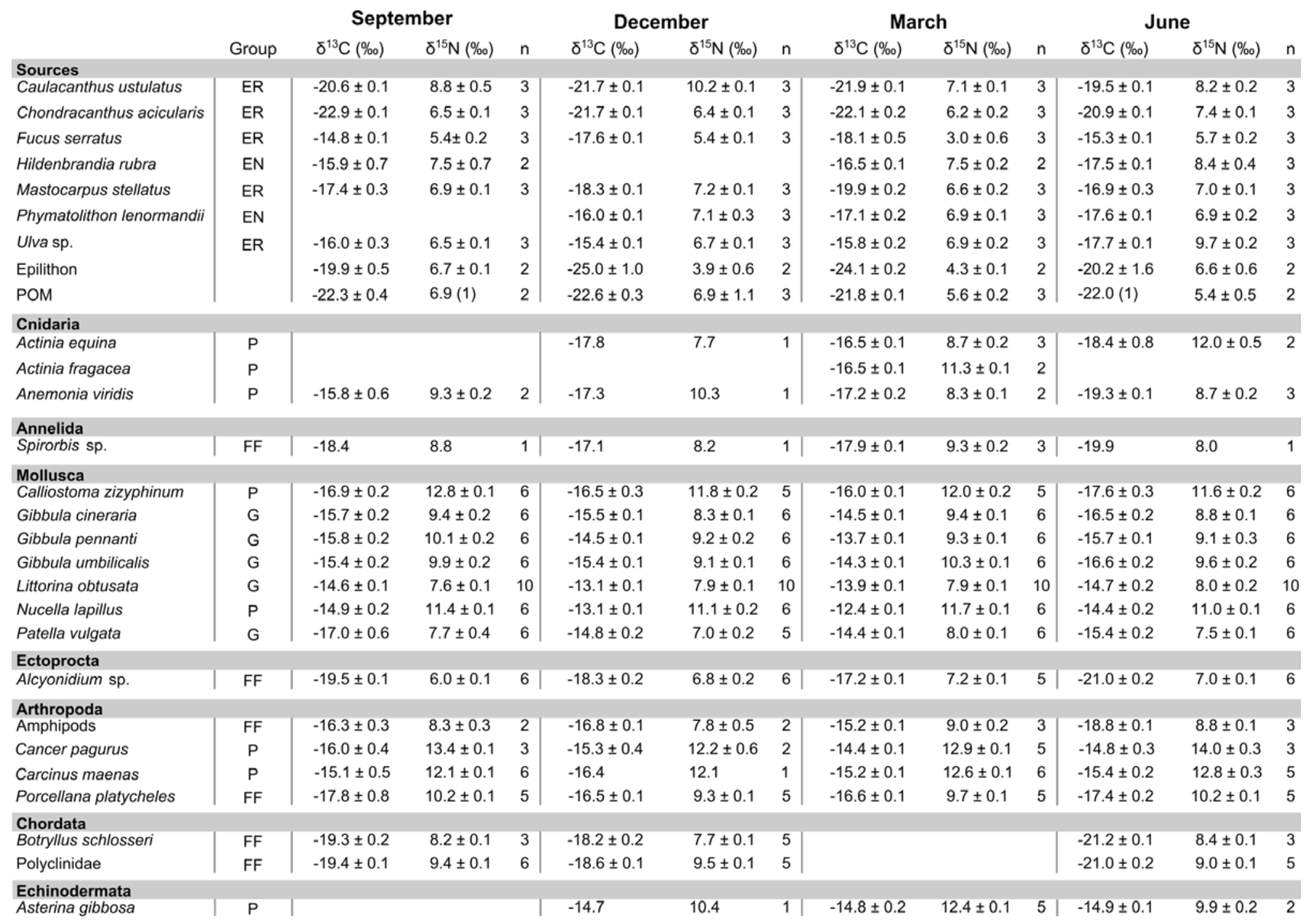

